Don Rodrigo Calderón o el emblema de una caída estrepitosa: sátiras del Conde de Villamediana...

\title{
DON RODRIGO CALDERÓN O EL EMBLEMA DE UNA CAÍDA ESTREPITOSA: SÁTIRAS DEL CONDE DE VILLAMEDIANA CONTRA UN MINISTRO DE FELIPE III
}

\author{
Karidjatou Diallo \\ Universidad de Bouaké - Costa de Marfil
}

\section{INTRODUCCIÓN}

El rápido ascenso político y la caída vertiginosa de don Rodrigo Calderón, marqués de Siete Iglesias, en el siglo XVII han motivado estos dos últimos siglos ${ }^{1}$

\footnotetext{
1 Si bien es verdad que la tragedia personal de este ínclito personaje ya hizo correr mucha tinta en los siglos XVII-XIX (cf., entre otros, los manuscritos 1818, 2244, 3795, 4049, y VC/1720/45 de la BN de Madrid; J. Monreal, «Don Rodrigo en la horca», en Cuadros Viejos. Colección de pinceladas, toques y esbozos, Madrid, Oficinas de la Ilustración Española y Americana, 1878, pp. 390-437; R. Navarrete y Landa, Don Rodrigo Calderón o la caída de un ministro, Madrid, Imprenta de Repullés, 1841; M. de Novoa, Memorias, Madrid, Ginesta, $1875 \ldots$, cabe reconocer que entre 1900 y 2010, el tema vuelve a ser de actualidad con el florecimiento de obras (además de las arriba citadas) como las de F. C. Sainz de Robles, Vida, proceso y muerte de Rodrigo Calderón, Barcelona, Iberia, 1932; J. Martínez Ruiz, El político, Madrid, Suc. de Hernando, 1908, etc.
} 
la publicación de artículos, estudios y obras que abordan parcial o enteramente su desgracia desde un punto de vista histórico (S. Martínez Hernández, 2009), (M. Álvarez Martín, 2003), jurídico (A. Ossorio y Gallardo, 1918), literario (J. Matas Caballero, 2001), (K. Diallo, 2009), novelesco (M. Vargas-Zúñiga, 2003), médico forense (F. Carrascal Antón, 1984), etc.

Aunque este repentino interés por el insólito caso del desafortunado favorito del duque de Lerma aviva nuestra curiosidad, en este artículo nos proponemos abordar única y exclusivamente las poesías satíricas del Conde de Villamediana escritas contra él. Estas sátiras, identificadas con el marbete de «sátiras políticas» (Scholberg, 1971), (Etreros, 1983; 1993), son fácilmente enlazables con distintas etapas de la privanza del Marqués de Siete Iglesias. Pero, ¿qué es lo que satirizaban estas composiciones de Villamediana? ¿Cómo lo satirizaban? ¿Cuál era su finalidad?

\section{SÁTIRAS SOBRE LAS FLAQUEZAS DE LA PERSONALIDAD DE DON RODRIGO CALDERÓN}

Se trata de composiciones satíricas que fustigan visiblemente algunos puntos débiles de la personalidad de don Rodrigo como sus orígenes humildes, su ambición desmedida, su dudoso catolicismo, su falta de honorabilidad, su mala gestión política, etc. El conde de Villamediana, «el verdadero representante de la oposición satírica contra el gobierno de Felipe III ${ }^{2} »$, en sus sátiras contra don Rodrigo, sean virulentas o sarcásticas, terminaba casi siempre por recordarle su ascendencia plebeya. La procedencia de una humilde cuna era su fuente de inspiración predilecta para desprestigiar a don Rodrigo. Algunas alusiones a su clase social podían ser vehementes como en el siguiente poema, donde el poeta deja patente su indignación moral ante el éxito social del advenedizo ministro que salió de la nada para alcanzar, en muy poco tiempo, la cúspide del poder:

Poema $1^{\underline{3}}$
Qué venga hoy un triste paje
a alcanzar la señoría,
y a tener mas en un día
que en mil años su linaje,
bien será señor se ataje;
que es grandísima insolencia
qué venga a ser excelencia
un vergante, igran locura!,
si su Magestad lo apura,
tendrás Calderón pendencia.

2 T. Egido, Sátiras políticas de la España moderna, Madrid, Alianza, 1973, p. 25.

3 A. Pérez Gómez, Romancero a Don Rodrigo Calderón (1621-1800), Valencia, «...La fonte que mana y corre...», 1955, p. 137. 
La oposición antitética paje/señoría (vv. 1-2), un día/mil años (vv. 3-4) aumenta hiperbólicamente el cambio de categoría social del Marqués que saltó del extremo de la servidumbre al del órgano de mando sin apenas transición ${ }^{4}$. El poeta que juzga su ascenso de vertiginoso, insólito y atrevido expresa con ímpetu su disconformidad con los logros sociales del Marqués. La virulencia del poeta y la llamada de atención que contienen los versos 7-10, acentúan «la función admonitoria ${ }^{5}$ » del poema a la vez que avisan de futuras represalias contra don Rodrigo.

Al margen de esta arrebatada arremetida contra sus orígenes humildes, algunas composiciones de esta índole obedecían al único designio del Conde de desacreditar la ya quebrantada imagen pública del marqués de Siete Iglesias. Para muestra vale esta décima donde el autor pone en entredicho la fe católica de don Rodrigo, al sugerir que era calvinista. De su duda surge una contradicción: Si la fe católica es para la nobleza antigua (nobleza alta y con títulos) una seña de identidad, «Un gage de noblesse et donc de légitimité ${ }^{\prime} », \mathrm{y}$ todos esos nobles son cristianos viejos, ¿cómo don Rodrigo que es protestante puede ser un noble? Una vez más aparece, aunque tácitamente, el tema de los orígenes humildes del marqués de Siete Iglesias.

Poema 2 ${ }^{7}$ (D2)
María de Sandalín
en Amber[es] te parió,
matrona q[ue] en Dios creyó;
y en su fe como un rocín
de su maestro Calvín
te dio en leche la doctrina,
y no es cosa peregrina
si un hijo mal enseñado
por los pasos q[ue] [h]an andado
por esos mismos camina.

Otras sátiras, en cambio, respondían simplemente a su intención de herirle lo más hondo posible, faltándole abiertamente al respeto. En los cuatro primeros versos de la siguiente décima del poema 2, Villamediana se refiere a don Rodrigo como el hijo ilegítimo del duque de $\mathrm{Alba}^{8}$ (Aldabas, v. 5).

\footnotetext{
${ }^{4}$ Para más detalles sobre el cambio de estatuto social de don Rodrigo y sus distintos cargos, vid. E. González Blanco, Don Rodrigo Calderón, Madrid, Colón, 1930; M. Lafuente, Historia general de España, Madrid, Francisco de P. Mellado - J. Bernat, 1861-1866, t. VIII, pp. 246-247, entre otros.

${ }^{5}$ L. Schwartz Lerner, «Formas de la poesía satírica en el siglo XVII. Sobre las convenciones del género», Edad de Oro, VI (1987), pp. 215-234.

${ }^{6}$ E. Cros, Le sujet culturel. Sociocritique et psychanalyse, Paris, L’Harmattan, 2005, p. 139.

${ }^{7}$ Ésta es la segunda décima del poema del Conde que empieza por «Rodriguillo, juro cierto...» del manuscrito 3795 de la BNM.

${ }^{8}$ Según se contaba en la época, Villamediana se hizo eco de este desvarío que tuvo don Rodrigo: «Fue capaz de renegar de su propio padre -por ser un simple capitán- y de ofender la honra de su madre
} 
Poema 2 (D 3)

Padre no le confesabas, ni fue tan buena tu madre q[ue] se [le] conozca padre, y así en Flandes le buscabas. El de acá de las Aldabas, siendo como no se olía -joh, prudente!- resistía haciendo al silencio escudo, en el tiempo q[ue] cornudo tu diligencia le hacía.

Al contrario que las invectivas ${ }^{9}$ sutiles, Villamediana no solía usar rodeos cuando se trataba de atacar la desmedida ambición de don Rodrigo. Poemas como el número 3 constituyen una campaña denigrante dirigida contra el Marqués con alusiones a su mentor, el duque de Lerma. En esta composición en concreto, aunque se puede apreciar como tilda a ambos de ladrones mediante la comparación (vv. 1-8), no deja de recordar que don Rodrigo era un hombre de humilde cuna que consiguió hacerse un sitio entre los nobles a fuerza de manipulaciones. Si bien en los versos 9-14, hace hincapié en las flaquezas del Marqués, acaba juntando a los dos personajes al final del poema, tal vez para sugerir que no son más que los mismos perros con distintos collares a pesar de las diferencias sociales. En esta sátira que es también una crítica al veloz ascenso que conoció la carrera política de don Rodrigo en la Corte, el controvertido poeta usa intencionadamente la antítesis «grande/pequeño» (v. 3), «desnudo/vestido» (vv. 7-8) -que introduce una desnivelación entre las pretensiones sociales de don Rodrigo y sus orígenes humildes- para resaltar hiperbólicamente la diferencia entre el pequeño paje que era a su llegada a la Corte, sólo con lo puesto, y el personaje influyente en el que se convirtió.

${\text { Poema } 3^{10}}^{10}$
Don Rodrigo Calderón
quiso igualarse a su dueño
siendo grande, el tan pequeño
que apenas se puso el don
en esto de ser ladrón,
muy bien igualarse pudo
que le vió el mundo desnudo,
y ya le mira vestido.
Con titulo guarnecido
dosel, corona y escudo,
y con toda esta grandeza
(siyo acertara a decillo);

probando, allí mismo, en Flandes ser hijo del duque de Alba», F. C. Sainz de Robles, op. cit., p. 8.

9 K. R. Scholberg, Sátira e invectiva en la España Medieval, Madrid, Gredos, 1971, p. 11.

10 A. Pérez Gómez, op. cit., p. 128. 


$$
\begin{aligned}
& \text { tapar no pudo un portillo } \\
& \text { del muro de su nobleza } \\
& \text { sentido le han con flaqueza } \\
& \text { gentes que le quieren mal } \\
& \text { y él viendo de ésto señal, } \\
& \text { y su opinión tan enferma } \\
& \text { ha se retirado a Lerma } \\
& \text { con el Duque Cardenal. }
\end{aligned}
$$

En las sátiras de Villamediana contra don Rodrigo, destacan también algunas referencias a su mala gestión política. En estas composiciones generalmente burlescas, el poeta identificaba a un grupo de personas, encabezado por el duque de Lerma, como sus confabulados. Tanto éstos como don Rodrigo eran víctimas de sus versos denunciadores y recriminatorios. Todos recibían indiscriminadamente sus dardos viperinos, aunque el duque de Lerma y don Rodrigo fueron los más perjudicados. Las fórmulas para esas críticas «entre burlas y veras ${ }^{11}$ » al mal gobierno del Marqués y a sus supuestos cómplices son el diálogo -ilustrado por el poema 4- y la lista onomástica, una especie de lista negra donde constan los nombres de esos pretendidos aliados en el fraude de don Rodrigo acompañados de sus respectivos comentarios sarcásticos.

\section{$\underline{\text { Poema } 4^{12}}$}

- Ya la parte de caza está pagada.

- ¿Y qué pide Hinestrosa?

- Señoría.

- ¿Y Juan Gutiérrez?

- Título quería de una huerta que tiene su cuñada.

Don Fadrique, señor, barbas, no es nada;

Don Pedro de Padilla, ¡niñería!

No pide más que ver si otro tenía

más necedad que él: ¡Cosa excusada!

- ¿Qué piden Don Fernando y Don Galindo?

- Dos hábitos de pruebas reservadas.

- ¿Qué pide Pedro López?

-Un gobierno.

- Mil gritos hoy me acosan; ya me rindo.

- Vuecencia las deja bien pagadas;

Dios les dará su premio... en el infierno.

Esta lista podía ser restringida. El poema 5 recoge el apellido, el título nobiliario o el apodo de algunos ilustres personajes contemporáneos de don Rodrigo, que aparecían a menudo en las sátiras de la época y cuya imagen pública se asociaba, por lo general, con la suya o con la del duque de Lerma:

11 A. Pérez Lasheras, Más a lo moderno (sátira, burla y poesía en la época de Góngora), Zaragoza, Universidad de Zaragoza, 1995, p. 29.

12 J. F. Ruiz Casanova, El Conde de Villamediana. Poesía impresa completa, Madrid, Cátedra, 1990, p. 435. 


\section{$\underline{\text { Poema } 5} \underline{13}$}

Tras de estos van en hileras

Heredia, Soria y Mejía;

que cada cual merecía estar bogando en galeras.

Otros de varias maneras

y Don Caco de Aragon,

Salazar y Calderon, como ladrones de fama, sigue cada uno la rama mas propia en su inclinación.

La lista podía ser también amplia y abierta a muchos más personajes, sean políticos o no, que tuvieron alguna relación con el tándem marqués de Siete Iglesias/ duque de Lerma. En el poema 6 por ejemplo, Villamediana arremete contra todos los validos del reinado de Felipe III satirizando a cada uno de ellos a través de frases hechas o que lo parecen:

\section{Poema $6^{14}$}

$\begin{array}{ll}\text { UCEDA: } & \text { Esconde la mano y tira la piedra. } \\ \text { OSUNA: } & \text { Nápoles llora su buena fortuna. } \\ \text { ACEVEDO: } & \text { Está muy quedo. } \\ \text { SAN GERMÁN: } & \text { No tuvo un plan hasta que fue a Milán. } \\ \text { EL MARQUÉS: } & \text { Si hurtó o no, yo no lo sé. } \\ \text { EL CONFESOR: } & \text { Si muere mártir será mejor, si escapa. } \\ \text { CALDERÓN: } & \text { Bástale una oración. } \\ \text { BONAL: } & \text { A sí ha hecho bien y a todos mal. } \\ \text { TAPIA: } & \text { El premio de la escarpia. } \\ \text { CERIZA: } & \text { Como tiembla se eriza. } \\ \text { No digo de LERMA: } & \text { Aunque está frío quema, } \\ & \text { «Iam recessit, sicut fumus». }\end{array}$

En el listado de personajes en el punto de mira de Villamediana, cabían también los motes que le servían para ridiculizar a los aludidos, sacando a relucir sus fechorías o destapando algún secreto bien guardado. En la siguiente sátira, se aprecia como identifica a cada personaje con un mote específico que acompaña (o no) su nombre:

\section{Poema $7^{15}$}

Restituya Rodriguillo

lo que ha hurtado, ipese a tal!;

y el señor doctor Bonal

lo que tiene en el bolsillo.

Visiten a Periquillo

y al palestino Tovar

y no se piense quedar

\footnotetext{
13 A. Pérez Gómez, op. cit., pp. 131-132.

14 T. Egido, op. cit., p. 85.

15 J. F. Ruiz Casanova, op. cit., p. 1002.
} 
el otro guardadoblones;

a don Pedro de Quiñones,

señor, lo habéis de encargar.

En lo que se refiere a la caída en desgracia de don Rodrigo, distinguimos varias sátiras que la describen con acritud. Son composiciones que relatan su declive, su arresto y reflejan el regocijo del poeta por la desgracia ajena. En este punto se puede apreciar claramente la falta de piedad de los versos que emanaron de la pluma de Villamediana contra él.

El declive: Manejando a la perfección la metáfora, Villamediana cuenta minuciosamente la caída estrepitosa de don Rodrigo desde la cumbre del poder y sus repercusiones sobre su entorno inmediato (poemas 8 y 9). Para él, si la presencia del Marqués en la Corte fomentaba las intrigas y maquinaciones de sus colaboradores, el fin de su valimiento no sólo las sacó a la luz (Poema 8), sino que destapó también las debilidades de una privanza antaño intocable (Poema 9), que fue perdiendo terreno con el destierro del duque de Lerma, la llegada del conde-duque de Olivares, y se extinguió con la ejecución de don Rodrigo ${ }^{16}$ :

$$
\begin{aligned}
& \underline{\text { Poema }}^{17} \\
& \text { Cayó la Tapia, y en ella } \\
& \text { tropezaron mil culpados, } \\
& \text { que el peso de sus pecados } \\
& \text { los trajo al suelo con ella. } \\
& \text { La casa en extremo bella, } \\
& \text { de Angulo desierta está } \\
& \text { su dueño la ocupará, } \\
& \text { como Calderón la suya } \\
& \text { sinó le da Dios su ayuda, } \\
& \text { que harto milagro será. }
\end{aligned}
$$

$$
\text { Poema } 9 \underline{18}
$$

Un pilar han derribado con tanta fuerza y ruido que de un golpe se han caído siete iglesias de su estado y si el pilar ha faltado y rompido tanto el quicio no es mucho que un edificio si fuerte, bravo y bizarro sobre columnas de barro haya hecho tan gran vicio.

\footnotetext{
16 M. Lafuente, op. cit., p. 249.

17 A. Pérez Gómez, op. cit., p. 130.

18 Ibidem., p.133.
} 
La hipérbole que impregna los versos 1-4 del poema 9 resalta la contundencia de la caída de don Rodrigo que, al igual que una onda expansiva, sacudió todo un Estado. Efectivamente, con la retirada del Duque y el arresto de don Rodrigo, se ponía fin a la hegemonía del clan de los Sandoval en la Corte, y se iniciaba la era de los Guzmán-Zúñiga ${ }^{19}$. De ahí la acertada alegoría del «pilar derribado».

En algunas de sus sátiras burlescas, el conde de Villamediana se erigía en defensor de la ideología $\mathrm{a}^{20}$ conservadora vigente en el barroco. Insinuaba su adhesión a «los controles de la movilidad social ascendente» por «procurar que cada uno siguiera en el puesto que un orden tradicional y heredero le tiene asignado ${ }^{21}$ ». Para él, un poeta de ascendencia noble, era intolerable que un plebeyo como don Rodrigo accediera a las altas esferas del poder, se codeara con la nobleza antigua y tuviera voz y voto en las decisiones relacionadas con el porvenir de España. El poema 10 resume irónicamente su postura y celebra el arresto de don Rodrigo a quien recuerda, con un falso pesar, que se habría librado del patíbulo si se hubiera conformado con la vida de paje que le correspondía:
Poema $10^{22}$
Mucho me pesa don Rodrigo, hermano, de veros apear de caballero adonde está el aplauso cortesano, aunque con mil resabios de escudero. Mejor os estuviérades villano, y escaparais de cuartos á un caldero: Del hado fue profética amenaza, pendencia con verdugo y en la plaza.

El encarcelamiento: Desgraciadamente para don Rodrigo llega su inesperado arresto, en la madrugada del 19 de febrero de 1619, a manos del Oidor del consejo don Francisco Rodríguez Fariñas ${ }^{23}$. Inmediatamente después, es llevado al castillo de la Mota de Medina del Campo y trasladado luego a la prisión del Estado de Montánchez (Extremadura). Lo que inspiró una nueva sátira de Villamediana (poema 11) en la que establecía una analogía entre la aludida prisión y la herrería, siendo el herrero el guardián, y el caldero forjado -Calderón por antonomasia-, el preso ${ }^{24}$. En esta sátira

19 S. Martínez Hernández, Rodrigo Calderón. La sombra del valido. Privanza, favor y corrupción en la corte de Felipe III, Madrid, Centro de Estudios Europa Hispánica, 2009, p. 333.

20 El concepto de «ideología» es según la definición de T. V. DIJK, Ideología y discurso. Una introducción multidisciplinaria, Barcelona, Ariel, 2003, p. 14.

21 J. A. Maravall, La cultura del Barroco, Barcelona, Ariel, 2002, p. 278.

22 A. Pérez Gómez, op. cit., p. 137.

23 J. Monreal, op. cit., p. 398.

${ }_{24}$ M. de la Campa, «Los sonetos satíricos de Villamediana», en I. Arellano et alii (eds.), Crítica textual y anotación filológica en Obras del Siglo de Oro, Actas del Seminario, Madrid, Castalia, 1991, pp. 46-89. 
destaca también una alusión a la célebre y vituperada indolencia de Felipe III (vv. 9-11):

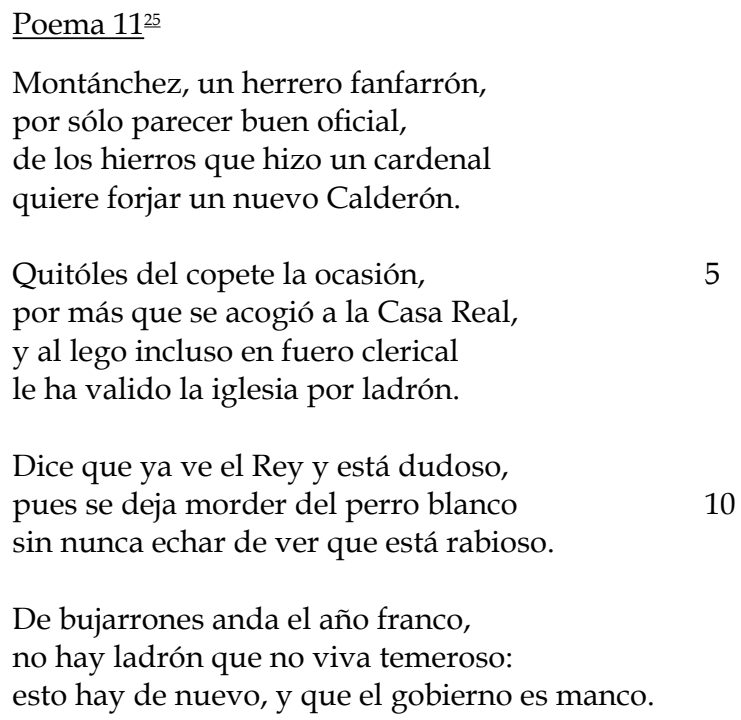

En ocasiones, quizás movido por el remordimiento y el sentimiento de culpa por sus diatribas acerbas, Villamediana intentaba justificar -en clave irónica- su ensañamiento con el Marqués. En la décima 1 del poema 2 (vid. nota 7), al amparo de «quien puede contenerse y no escribir sátiras a la vista de una ciudad inicua» de Juvenal (versos 5-8), el poeta clava otro de sus dardos al tocado Marqués:

Poema 2 (D1)

Rodriguillo, juro cierto que me pesa de hablar porq[ue] no digan $\mathrm{q}[\mathrm{ue}]$ es dar lanzadas en moro muerto.

Pero en campo tan abierto

hasta los mudos obliga

a que, aunq[ue] por señas, diga

cada cual lo que sintiere;

y si diere y a quien diere,

$\mathrm{S}[\mathrm{an}]$ Pedro se la bendiga.

El regocijo por la desgracia ajena: En el poema 12, el conde de Villamediana fiel a su estilo satírico-burlesco que le atrajo más de un disgusto ${ }^{26}$, expresa sin remordimientos su alegría al imaginar a don Rodrigo en manos de un adversario tan inflexible como la muerte. En este verdadero canto de júbilo por la desgracia de don Rodrigo, Villamediana da por sentado que ha sonado la hora de la venganza de la

25 J. F. Ruiz Casanova, op. cit., p. 448.

26 J. Cárdenas Ponce, Góngora y la poesía culta del siglo XVII, Madrid, Laberinto, 2001, p. 135. 


\section{Karidjatou Diallo}

muerte sobre nuestro Marqués quien, a su parecer, la manejó a su antojo durante toda su privanza (vv. 1-3). La exaltación del satírico se debe, desde nuestro punto de vista, a que al morir don Rodrigo, probaría por fin de su propia medicina y experimentaría en carne propia lo que hizo a otros. Su postura nos recuerda este fragmento del pregón que precedía a la comitiva de don Rodrigo el 21 de octubre de 1621, día de su ejecución: «[...] quien tal hizo, que tal pague ${ }^{27} »$. Fragmento que no es más que una interpretación del refrán popular «Quien a hierro mata, a hierro muere»:

Poema $12^{28}$
Rodrigo, en poder estás
de la muerte, a quien mandaste
todo el tiempo que privaste,
y a los médicos, que es mas.
Si, por dicha, al cielo vas,
poco seguro estaría,
aunque posible sería
que permita Dios que tenga
Dimas en quien se entretenga,
y que le hagas compañía.

Villamediana, al contrario que sus contemporáneos barrocos que se servían de la «técnica de la alusión ${ }^{29}$ » para determinar el tema y el blanco de sus composiciones satíricas, no deja margen para la duda. En casi todas sus sátiras contra don Rodrigo, le pone en evidencia mediante la figura retórica del apóstrofe, llamándole por su nombre, su apellido o por el despectivo «Rodriguillo», lo que acentúa la función apelativa de sus composiciones. A pesar de que en ocasiones alude a don Rodrigo metafóricamente, deducimos de nuestro estudio que Villamediana personaliza sus sátiras para dar a entender que asume la entera responsabilidad de sus composiciones así como las consecuencias de sus actos. Confirma así su fama de provocador, despiadado, «mordaz y terrible satírico ${ }^{30} \gg$.

\section{ALGUNOS PROCEDIMIENTOS}

Además de las clásicas figuras retóricas, paradigmas de las sátiras barrocas (metáforas, oxímoron, juegos de palabras...) y de las típicas composiciones virulentas, burlescas e inoportunas del inagotable Conde contra don Rodrigo, existen otras de

27 E. González Blanco, op. cit., p. 52.

28 A. Pérez Gómez, op. cit., p. 16.

29 M. Etreros, La sátira política en el siglo XVII, Madrid, Fundación Universitaria Española, 1983, p. 128.

30 R. Cacho Casal, «La sátira en el siglo de oro. Notas sobre un concepto controvertido», Neophilologus 88 (2004), pp. 61-72. 
distinta índole que se caracterizan por su tono admonitorio y exhortativo. Son las advertencias, constituidas a su vez por los poemas satírico-morales y los avisos.

Los poemas satírico-morales: Formadas por la mezcla de contenidos satíricos y de tonos moralizadores, se materializan en las composiciones tomando el aspecto de una moraleja o un decir que se coloca al final del poema. En el poema 13, que es de tono moralizador, encontramos el manoseado tópico barroco de la vanitas. Aquí, el conde de Villamediana advierte de la vanidad del poder por ser un logro efímero. Con el oxímoron «los dichosos desgraciados» (v.6), plasma la ingenuidad de los políticos que en su lucha por alcanzar la cumbre del poder no escatiman esfuerzos, ignorando quizás que lo más difícil no es conseguir el anhelado poder, sino conservarlo. El juego de palabras «estrellas/estrelladas» refuerza irónicamente esta idea. La décima, por sugerir que todo ascenso, por mínimo que sea, está sujeto a la fuerza de la gravedad, es «todo un aviso para aquellos que, ambiciosos, pretenden un logro social ${ }^{31}{ }$ :

${\underline{\text { Poema } 13^{32}}}_{\text {Sea asombro a los mortales }}$
y ejemplo para el que priva;
pues subir muy arriba
bajar hace á extremos tales.
Teman casos desiguales
los dichosos desgraciados,
que con alas de privados
se suben a las estrellas,
y que sólo sacan de ellas
volver al suelo estrellados.

En lo que se refiere a los avisos, definidos por el DRAE como «noticia o advertencia que se comunica a alguien; indicio, señal o consejo», en las sátiras de Villamediana contra don Rodrigo se reparten entre las profecías y los refranes ${ }^{33}$ :

Los refranes: Uno de los rasgos de la poesía barroca con el que topamos en muchas composiciones satíricas es la frase lapidaria o el refrán. Debido a su gran valor connotativo y a su papel moralizante, el refrán tiene un carácter versátil que le permite servir tanto para ridiculizar como para sermonear o infundir ánimo, dependiendo del contexto en el que se usa. Suele intercalarse en las composiciones:

\footnotetext{
31 R. Andrés, Tiempo y caída. Temas de la poesía barroca española, Barcelona, Quaderns Crema, 1994, p. 93.

32 Ésta es la décima 5 del poema del Conde que empieza por «Golpes de fortuna son/ vueltos ya contra su dueño», en A. Pérez Gómez, op. cit., pp. 126-127.

33 Para una definición completa y detallada de los refranes y profecías, remito a los estudios entre otros de J. Cantera Ortiz / J. Sevilla Muñoz, Pocas palabras bastan. Vida e interculturalidad del refrán, Salamanca, Diputación, Centro de Cultura Tradicional, 2008.
} 
Sea plasmándose en el poema sin ningún atisbo de burla ni de segundas intenciones, y $\sin$ apenas alteraciones formales. Es lo que García-Page llama «reproducción literal ${ }^{34} »$ :

\section{Poema $14^{35}$}

\section{Porque quien hurta al ladrón, dice un refrán en mi tierra, cien años de perdón gana y muchas indulgencias ${ }^{36}$}

Sea distribuyéndose la idea general del refrán por todos los versos del poema, ampliando así su alcance pero haciéndole perder parte de su estructura sintáctica. Esta técnica que es la de «la supresión ${ }^{37}$ » de García-Page, tiene algunos presupuestos de la teoría de la «deconstrucción» de J. Derrida. Se puede apreciar este malabarismo literario con un refrán en el poema 15. Del refrán original, «Cuando la barba de tu vecino veas pelar, pon la tuya a remojar», Villamediana ha conservado sólo el final: «Y echa tu barba en remo-» (v. 4). Dado que, en el fondo, lo que pretende es avisar de un peligro inminente aconsejando escarmentarse con lo que les pasa a otros, creemos que el poeta se conformó con que predominara esta idea sin necesidad de mantener la estructura original y completa del refrán:

\section{${\underline{\text { Poema } 15^{38}}}^{38}$ \\ Don Rodrigo Calderó-, atiende el tiempo que pa-, saca el dinero de ca-, y echa tu barba en remo-. Teme al tercero Fili-, que, aunque el castigo dila-, muy bien asienta la ma-, esto te avisa un ami-.}

Sea retocando el refrán cambiando una ínfima parte de su estructura oracional para simplificarlo, o conservando la frase principal y modificando la subordinada, o viceversa. Esto es la «sustitución sintagmática ${ }^{39}{ }$ de García-Page:

\footnotetext{
34 M. García-Page, «Texto paremiológico y discurso poético. El ejemplo de Gloria Fuertes», Paremia I (1993), p. 45-53.

35 Representan los versos 49-52 del poema del Conde que empieza por «Un pastor de Fuencarral, / de Madrid cercana aldea» en E. Cotarelo y Mori, op. cit., p. 286.

36 «Refrán con que se disculpa el que comete una mala acción contra un malvado o con que uno mismo justifica una acción mala aduciendo su buen fin», G. Doval, Refranero temático español, Madrid, Ediciones del Prado, 1997, p. 24.

37 M. García-Page, op. cit., p. 49.

38 Según J. F. Ruiz Casanova, «Villamediana escribió estas redondillas basándose en una anécdota según la cual, Calderón había tomado la precaución de ocultar en varios conventos de Valladolid alhajas y papeles que podían comprometerle», op. cit., p. 360.

39 M. García-Page, op. cit., p. 51.
} 


\section{Cántaro que muchas veces}

va a la fuente allá se queda ${ }^{40}$

(Poema 14, vv. 69-72)

Y si diere y a quien diere,

S[an] Pedro se la bendiga ${ }^{41}$.

(Poema 2, vv. 9-10)

Las profecías: En lo tocante a ellas, se puede decir que consciente del poder de convicción que ejercía sobre la opinión pública, y ayudado por la fuerte superstición de la época, el poeta se sirvió de ellas para augurar la futura desgracia del marqués de Siete Iglesias. Daba así a entender que su infortunio era de prever porque él ya lo había profetizado. Este medio de persuasión es muy característico de «la última etapa de poeta satírico de Villamediana donde se vislumbra con claridad el asomo del connatural mesianismo en sus producciones ${ }^{42}$ ».

Además de su carácter premonitorio, las profecías iban envueltas de un peculiar tono irónico que podía ser sutil, como en el poema 15 (vid supra) donde Villamediana avisaba a don Rodrigo de la inminencia de un castigo real. En la composición, detrás de lo puramente profético se escondía un aviso al Marqués para que extremara las precauciones y se amparara de la ira de Felipe III. Parece que de haber seguido los consejos del poeta, no habría tenido un final tan trágico.

Algunas profecías tenían el inequívoco tono sentencioso del oráculo seguro de su don de adivinación. Esto se refleja en el poema 16, un pareado basado en una disputa que tuvo el Marqués con uno de los altos mandos militares de Felipe III llamado Verdugo, el 3 de marzo de 1615 en la Plaza Mayor ${ }^{43}$. Villamediana vio en este enfrentamiento un signo premonitorio de la futura ejecución de don Rodrigo en ese mismo sitio:

\section{${\underline{\text { Poema } 16^{44}}}^{40}$}

Pendencia con verdugo y en la plaza mala señal sin duda te amenaza.

\footnotetext{
40 Variante del refrán «Tanto va el cántaro a la fuente, que allí deja el asa o la frente», que advierte que el que frecuentemente se expone a los peligros suele finalmente sufrir las consecuencias de ello. G. Doval, op. cit., p. 173.

41 Refrán retocado que inicialmente era: «A quien Dios se la dé, San Pedro se la bendiga». Es un refrán ambivalente que tanto vale, pues, para mostrar indiferencia ante algo circunstancial como para hacer acatamiento a los dictados de la voluntad divina. L. Junceda, Diccionario de refranes, Madrid, EspasaCalpe, 1994, p. 48.

42 T. Egido, op. cit., p. 27.

43 J. Monreal, op. cit., pp. 416-417.

44 A. Pérez Gómez, op. cit., p. 136.
} 
A la vista de estas distintas premoniciones que acabaron confirmándose, un interrogante afloja: ¿por qué tantos avisos, presagios y tanta convicción sobre un eventual castigo ejemplar de don Rodrigo?

Para nosotros, estos avisos y premoniciones podrían tener una explicación más pragmática. Seguramente no eran más que un ardid para, por una parte atemorizar a don Rodrigo y desestabilizarle emocionalmente ${ }^{45}$, y por otra, informar al pueblo de las futuras represalias que se estaban preparando contra uno de sus pretendidos expoliadores. Probablemente estas pseudo-profecías provengan de las reuniones palaciegas, las murmuraciones que procedían de círculos cercanos al Rey, o partan de hechos tan insólitos como la ya aludida disputa que tuvo el malogrado marqués en la plaza Mayor con don Fernando Verdugo. Por lo que deducimos que lejos de ser un vidente, Villamediana no era más que un oportunista que supo sacar ventaja de las privilegiadas informaciones que recibía debido a su rango social, a sus títulos nobiliarios y a sus vínculos con la Corte de Felipe III.

\section{EL DESIGNIO DE SUS SÁTIRAS CONTRA DON RODRIGO}

Las pertinentes y constantes sátiras del Conde contra el favorito del duque de Lerma agudizan tanto nuestra curiosidad que nos llevan a intentar despejar las siguientes incógnitas: ¿Por qué Villamediana se ensañó tanto con don Rodrigo Calderón habiendo más miembros en el gobierno del duque de Lerma? Si don Rodrigo no era más que un mandado, ¿qué motivaba esta ubérrima producción satírica de Villamediana en su contra? Disponemos de las respuestas de distintos estudiosos de la sátira barroca para ayudarnos a subsanar las dudas planteadas.

Etreros, refiriéndose a las sátiras escritas contra todo el gobierno del duque de Lerma, habla de «una animadversión personal, un deseo de provocación, una rebeldía elemental en sus manifestaciones ${ }^{46} »$.

García García se atiene al afán de provocación y de revancha del Conde porque para él, el intrépido poeta desempeñó un papel clave en el proceso de desprestigio de don Rodrigo con sus sátiras que constituyeron «una forma audaz de entretenimiento, desafío y venganza frente a las sucesivas facciones dominantes ${ }^{47}$ ».

45 Los ataques constantes a sus orígenes y a su estatuto social acabaron afectando a la personalidad de don Rodrigo. Y no sería descabellado pensar que aumentaron la paranoia que según Carrascal Antón, sufría. F. Carrascal Antón, Don Rodrigo Calderón. Entre el poder y la tragedia, Valladolid, Ayuntamiento de Valladolid, 1997.

46 M. Etreros, «La sátira política, discurso del barroco español», Separata del Boletín de la Real Academia Española, tomo LXX, cuaderno CCLI, (1990), pp. 569-586.

47 B. J. García García, «La sátira política a la privanza del duque de Lerma» en F. J. Guillamón Álvarez et 
Cotarelo y Mori, en cambio, ve en ello una muestra de su patriotismo ante la pésima imagen que ofrecía la Corte a su regreso de Italia en $1617^{48}$.

Sin duda las distintas respuestas son válidas porque por una parte, la Corte bajo Felipe III tenía fama de ser de todo, excepto seria y responsable. Era una Corte viciada por el despilfarro, la corrupción, el nepotismo, el desbaratamiento..., y cuya imagen se deterioraba progresivamente ante la benevolente mirada de un rey indolente que se preocupaba más por sus diversiones que por el Reino. Villamediana, que no dejaba escapar ni la más mínima oportunidad para llamar la atención sobre la vergonzosa corrupción del gobierno, convirtió sus denuncias en una guerra personal y se convirtió a sí mismo en «un elemento incómodo para el poder y, a la vez, en el recordatorio viviente de sus faltas ${ }^{49}{ }$.

Y por otra, si Villamediana aborrecía al Duque y a su séquito por institucionalizar la corrupción con sus corolarios, odiaba más al marqués de Siete Iglesias por sus orígenes plebeyos, por ocupar un privilegiado puesto dentro del gobierno de Felipe III sin ser noble, y sobre todo por carecer de escrúpulos a la hora de percibir prebendas, títulos y cargos. De ahí que se propusiera llevar a cabo una campaña denigratoria en su contra para disimular su propia sed de justicia.

Sin embargo, reducir toda esta producción satírica del Conde a la «animadversión personal», las difamaciones, la provocación, la venganza y el simple patriotismo, sería resaltar únicamente su vertiente subjetiva, es decir, la que la circunscribe a «un desahogo puramente personal que sólo presenta los prejuicios y odios del autor ${ }^{50}$ ». Entonces, se dejaría de lado la dimensión social de las sátiras políticas barrocas que es «criticar las costumbres y vicios de personas o grupos sociales, con propósito moralizador, meramente lúdico o intencionadamente burlesco ${ }^{51} \gg$.

No obstante, hay que recordar que desde el punto de vista social, las sátiras de Villamediana desempeñaron un papel decisivo ya que aceleraron la caída en desgracia de don Rodrigo al denunciar asidua y abiertamente el malestar general provocado por su gobierno corrupto ante el pueblo, en círculos muy cercanos a la Corte e incluso en el mismo Palacio Real. Por lo que estas tres respuestas aunque certeras resultan insuficientes.

alii (eds.), Lo conflictivo y lo consensual en Castilla, Sociedad y poder político 1521-1715, Homenaje a Francisco Tomás y Valiente, Murcia, Universidad de Murcia, 2001, p. 292.

48 Cotarelo y Mori, op. cit., p. 62.

49 D. F. Arranz Lago, «La afirmación identitaria de Quevedo y el discurso social del siglo XVII», Dicenda, 27 (2009), pp. 5-18.

${ }^{50}$ K. R. Scholberg, op. cit., p. 9.

51 D. Estébanez Calderón, Diccionario de términos literarios, Madrid, Alianza editorial, 2004, p. 964. 
Tras el arresto de don Rodrigo y la llegada al valimiento del clan de los «Guzmán/Zúñiga», una cuarta hipótesis, defendida por Rosales, se afianza: Las aspiraciones políticas del conde de Villamediana ${ }^{52}$. Si nos atenemos a esta idea, las sátiras de Villamediana, más que unas composiciones provocadoras, denigrantes, denunciadoras y desacreditadoras, eran unas meras maniobras de distracción que encubrían sus pretensiones políticas porque generalmente atacaban directamente «a los gobernantes que formaban parte de círculos del poder enemigo de su propia orientación ${ }^{53} »$. En sus manos, la sátira se convirtió en el arma propagandística idónea ya que contribuyó eficazmente al cambio de mando político.

Huelga decir aquí que para hacer realidad sus anhelos políticos, Villamediana se valió de la filosofía de Maquiavelo usando su pluma como medio para conseguir un único fin: Arrojar a don Rodrigo de su encumbrado puesto político, aliviar al palacio de su molesta presencia y dejar así las riendas del gobierno de España a don Gaspar de Guzmán y Pimentel, el futuro conde-duque de Olivares con el que estaba seguro de alcanzar su meta. En nuestra opinión, su empeño y su inagotable fuente de inspiración burlona fueron decisivos en esta lucha por cubrirse de gloria. Tanto es así que nos atrevemos a sostener que fue uno de los activistas de la desdicha de don Rodrigo. Si bien es verdad que atacó a discreción a todo el gobierno del duque de Lerma, se cebó en una pieza importante de esa administración, la que servía de vínculo entre el pueblo, la nobleza y el valido: Don Rodrigo Calderón. Era, a la vez, el pilar que sostenía el valimiento del Duque, el centro neurálgico de su gobierno y su eslabón más débil (debido a su desmedida ambición, a sus orígenes humildes y a otras flaquezas de su personalidad). Por consiguiente, para desestabilizar el gobierno de Lerma simplemente había que hundir a don Rodrigo, lo que hizo Villamediana al elegirle como blanco favorito de sus diatribas burlescas y convertirle en «un pararrayos que atrae todas las quejas y protestas ${ }^{54} \gg$.

Las cuatro posturas que hemos venido analizando son, a nuestro juicio, complementarias. Villamediana ha sabido sincronizar sus aspiraciones personales con la crítica de los abusos socio-políticos del gobierno de Lerma. Pensamos que tras la cortina de humo de las denuncias sociales y diatribas acerbas, supo esconder hábilmente sus verdaderas intenciones que no eran más que desviar la atención de la opinión pública hacia un único culpable de sus males al tiempo que se acercaba, a pasos agigantados, hacia la cima del poder. El conde de Villamediana ha aprovechado

\footnotetext{
52 L. Rosales, Pasión y muerte del conde de Villamediana, Madrid, Gredos, 1969, p. 179.

53 I. Arellano / V. Roncero, Poesía satírica y burlesca de los Siglos de Oro, Madrid, Espasa Calpe, 2002, p. 14.

54 F. Díaz Plaja, La vida y la época de Felipe III, Madrid, Planeta, 1997, p. 20.
} 
ingeniosamente uno de los rasgos de la sátira que es la denuncia. Ha delatado los vicios de don Rodrigo con un oculto designio: «Ganarse una aureola de popularidad, una aureola de hombre duro y de político limpio de $\operatorname{manos}^{55}$ », para granjearse la simpatía del pueblo llano. En su conquista del corazón de los españoles, se adjudicó el respeto del clan de los «Guzmán-Zúñiga» al ofrecerle en bandeja el mando de la política española con la desaparición del binomio Lerma/Calderón. Por lo que podemos declarar, de cara a todo lo dicho hasta ahora, que los motivos subyacentes de las sátiras de Villamediana escritas contra don Rodrigo son ambivalentes porque en parte son políticos y en parte sociales.

Basándonos en las composiciones satíricas que incluimos en este trabajo, se puede aventurar que con el pretexto de azotar a don Rodrigo denunciando sus fechorías, el conde de Villamediana llevó a cabo su cruzada personal contra todo el gobierno de Felipe III. Todos, sin excepción, pasaron por la mira telescópica de esta inagotable fuente de críticas acerbas que se erigió en la voz de su conciencia. Incluso el mismo rey recibió algunos dardos bien afilados que criticaban su indolencia ante el mal gobierno del duque de Lerma. Ahora bien, lo que echamos en falta en estas sátiras, es que el Conde en ningún momento haga una propuesta clara de mejoría del panorama político español de la época. Critica, denuncia, se burla, insulta y a veces avisa de la inminencia de un castigo para los malhechores, pero en ninguno de los poemas analizados formula una idea clara de lo que espera de los políticos. Esto es muy frecuente en las sátiras de la época.

Para terminar, se puede decir que en manos de Villamediana, todo lo relacionado con el tránsito político de don Rodrigo tomaba forma de sátira. Ni el más mínimo detalle de su privanza se le escapaba. Es más, parece que Villamediana era para don Rodrigo un molesto parásito que se hacía fuerte acumulando éxitos y aplausos a costa de su tormento y desgracia.

Si, como se dijo anteriormente (vid supra), Villamediana satirizó a don Rodrigo ora para alcanzar sus metas políticas, ora por «animadversión personal», ora simplemente para criticar a todo el gobierno de Felipe III como deber de todo satírico que anhela un mejor gobierno en su país, lo lógico es que se sintiera realmente aliviado tras su desaparición del ámbito político. Entonces, ¿por qué le dedicó algunas conmovedoras elegías tras su muerte ${ }^{56}$ ? ¿Sentimiento de culpa por haber contribuido activamente

\footnotetext{
55 L. Rosales, op. cit., p. 179.

56 Vid. la antología constituida por una servidora (poemas 49, 65, 69, 73, 78), K. Diallo, La figura de don Rodrigo Calderón a través de la literatura (S. 17-21), Madrid, Servicio de Publicaciones Universidad Complutense, 2009. Disponible en http://eprints.ucm.es/9547/1/T31055.pdf. (Consultado el 15-112011).
} 
a su desgracia o pura mímesis de la moda poética de la época, la que consistía en dedicar «una composición encomiástica a cualquier prócer muerto ${ }^{57}$ »? Procurar dar una respuesta a estas preguntas sería abrir otro capítulo sobre la intencionalidad de las sátiras del Conde contra el marqués de Siete Iglesias.

\section{BIBLIOGRAFÍA}

ÁLVAREZ MARTÍN, M., Personajes de Medina, Valladolid, Diputación de Valladolid, 2003.

ANDRÉS, R., Tiempo y caída. Temas de la poesía barroca española, Barcelona, Quaderns Crema, 1994.

ARELlANO, I. / RONCERO, V., Poesía satírica y burlesca de los Siglos de Oro, Madrid, Espasa Calpe, 2002.

ARRANZ LAGO, D. F., «La afirmación identitaria de Quevedo y el discurso social del siglo XVII», Dicenda, 27 (2009), pp. 5-18.

CACHO CASAL, R., «La sátira en el siglo de oro. Notas sobre un concepto controvertido», Neophilologus, 88 (2004), pp. 61-72.

CAMPA, M. De La, «Los sonetos satíricos de Villamediana», en I. Arellano et alii (eds.), Crítica textual y anotación filológica en Obras del Siglo de Oro, Actas del Seminario, Madrid, Castalia, 1991, pp. 46-89.

CÁRDENAS PONCE, J., Góngora y la poesía culta del siglo XVII, Madrid, Laberinto, 2001.

CARRASCAL ANTÓN, F., a - Don Rodrigo Calderón. Entre el poder y la tragedia, Valladolid, Ayuntamiento de Valladolid, 1997.

b - «Venturas y desventuras de don Rodrigo Calderón. Estudio médico legal de su momia y del entorno social de su época», Revista Jano de Medicina y Humanidades, 632 (1984), pp. 126-133.

COTARELO Y MORI, E., El Conde de Villamediana. Estudio biográfico-crítico, Madrid, Visor Libros, 2003.

CROS, E., Le sujet culturel. Sociocritique et psychanalyse, Paris, L'Harmattan, 2005.

DIALLO, K., La figura de don Rodrigo Calderón a través de la literatura (S. 17-21), Madrid, Servicio de Publicaciones: Universidad Complutense, 2009. http://eprints. ucm.es/9547/1/T31055.pdf (Consultado el 15-11-2011).

DÍAZ PLAJA, F., La vida y la época de Felipe III, Madrid, Planeta, 1997.

DIJK, TEUN A. V., Ideología y discurso. Una introducción multidisciplinaria, Barcelona, Ariel, 2003.

DOVAL, G., Refranero temático español, Madrid, Ediciones del Prado, 1997.

57 J. Matas Caballero, «Epitafios a don Rodrigo Calderón. Del proceso sumarísimo al sumario tópicoliterario del proceso», en I. Lozano-Renieblas et alii (eds.), Silva. Studia philologica in honorem Isaías Lerner, Madrid, Castalia, 2001, pp. 433-450. 
Don Rodrigo Calderón o el emblema de una caída estrepitosa: sátiras del Conde de Villamediana...

EGIDO, T., Sátiras políticas de la España moderna, Madrid, Alianza editorial, 1973.

ESTÉBANEZ CALDERÓN, D., Diccionario de términos literarios, Madrid, Alianza editorial, 2004.

ETREROS, M., a - La sátira política en el siglo XVII, Madrid, Fundación Universitaria Española, 1983.

b -«La sátira política, discurso del barroco español», Separata del Boletín de la Real Academia Española, tomo LXX, cuaderno CCLI (1990), pp. 569-586.

GARCÍA GARCÍA, B. J., «La sátira política a la privanza del duque de Lerma» en F. J. Guillamón Álvarez et alii (eds.), Lo conflictivo y lo consensual en Castilla, Sociedad y poder político 1521-1715: Homenaje a Francisco Tomás y Valiente, Murcia, Universidad de Murcia, 2001, pp. 261-295.

GARCÍA-PAGE, M., «Texto paremiológico y discurso poético. El ejemplo de Gloria Fuertes», Paremia, I (1993), pp. 45-53.

GONZÁLEZ BLANCO, E., Don Rodrigo Calderón, Madrid, Colón, 1930.

JUNCEDA, L., Diccionario de refranes, Madrid, Espasa-Calpe, 1994.

LAFUENTE, M., Historia general de España, Madrid, Francisco de P. Mellado - J. Bernat, 1861-1866, t. VIII.

MARAVALL, J. A., La cultura del Barroco, Barcelona, Ariel, 2002.

MARTÍNEZ HERNÁNDEZ, S., Rodrigo Calderón. La sombra del valido. Privanza, favor y corrupción en la corte de Felipe III, Madrid, Centro de Estudios Europa Hispánica, 2009.

MARTÍNEZ RUIZ, J. (Azorín), El político, Madrid, Suc. de Hernando, 1908.

MATAS CABALLERO, J., «Epitafios a don Rodrigo Calderón. Del proceso sumarísimo al sumario tópico-literario del proceso», en I. Lozano-Renieblas et alii (eds.), Silva. Studia philologica in honorem Isaías Lerner, Madrid, Castalia, 2001, pp. 433450.

MONREAL, J., «Don Rodrigo en la horca», en Cuadros Viejos. Colección de pinceladas, toques y esbozos, Madrid, Oficinas de la Ilustración Española y Americana, 1878, pp. 390-437.

NAVARRETE Y LANDA, R., Don Rodrigo Calderón o la caída de un ministro, Madrid, Imprenta de Repullés, 1841.

NOVOA, M. de, Memorias, Madrid, Ginesta, 1875.

OSSORIO Y GALLARDO, A., Los hombres de toga en el proceso de D. Rodrigo Calderón, Madrid, Biblioteca Nueva, 1918.

PÉREZ GÓMEZ, A., Romancero a Don Rodrigo Calderón (1621-1800), Valencia, «...La fonte que mana y corre...», 1955.

PÉREZ LASHERAS, A., Más a lo moderno (sátira, burla y poesía en la época de Góngora), Zaragoza, Universidad de Zaragoza, 1995. 
RODRÍGUEZ-MOÑINO, A., «Cancionero del Marqués deSiete Iglesias», en Curiosidades bibliográficas: Rebusca de libros viejos..., Madrid, Langa y Cía., 1946, pp. 19-33.

ROSALES, L., Pasión y muerte del conde de Villamediana, Madrid, Gredos, 1969.

RUIZ CASANOVA, J. F., El Conde de Villamediana. Poesía impresa completa, Madrid, Cátedra, 1990.

SAINZ DE ROBLES, F. C., Vida, proceso y muerte de Rodrigo Calderón, Barcelona, Iberia, 1932.

SCHOLBERG, K. R., Sátira e invectiva en la España Medieval, Madrid, Gredos, 1971.

SCHWARTZ LERNER, L. «Formas de la poesía satírica en el siglo XVII. Sobre las convenciones del género», Edad de Oro, VI (1987), pp. 215-234.

SEVILLA MUÑOZ, J. / CANTERA ORTIZ DE URBINA, J., Pocas palabras bastan. Vida e interculturalidad del refrán, Salamanca, Diputación, Centro de Cultura Tradicional, 2008.

TÉLLEZ, J., Don Rodrigo en la horca, Madrid, Delban, 1968.

TOMÁS Y VALIENTE, F., Los validos en la monarquía española del siglo XVII. Estudio institucional, Madrid, Siglo Veintiuno de España, 1990.

VARGAS-ZÚÑIGA, M., Del Sitial al Cadalso. Crónica de un crimen de estado en la España de Felipe IV, Barcelona, Belacqva/Carroggio, 2003. 